\title{
Gender in the Cultural Frame and Religious Value (Case Study of Bugis Couple Family)
}

\author{
Musdalia Mustadjar \\ Lecturer of Sociology, Faculty of Social Science, State University of Makassar \\ Gunungsari Baru Campus, Jl. Raya Pendidikan \\ E-mail: mus.mus754@yahoo.com;
}

Doi:10.5296/jsr.v4i2.4718

URL: http://dx.doi.org/10.5296/jsr.v4i2.4718

\begin{abstract}
This research is done in Makassar, in order to explain comprehension and interpretation of gender and implementation of the 5 Buginese man and wife as informants based on life-guidance, social relation, patriarchy perception, social behavior, and woman's double role. This research uses qualitative method with case study and phenomenological. The informant's is determined purposively, they are the 5 Buginese man and wife with double role case, whether those who are civil servants, entrepreneur, politician, or home industry actors. This research's result shows that 5 cases of Buginese man and wife informants understand and interpret gender as agreement and conformity of man's and woman's function in taking the role based on cultural and religious value, which are siri', pangaderreng, sipakatau, sipakalebbi, and teppe', as included in life-guidance because those values become binding frame of man and wife in gender implementation. Gender equality implication with women's double role in 5 Buginese man and wife as informants case are realized in the financial development, spiritual gift, motivation and achievement of themselves and family, because Buginese citizens on that case do not prohibit their wives to work and the religion is allowing wives to have 2 roles, but they need to keep siri', self esteem and also the agreement from the husband. Spending time at home with husband in the evening is less in quantity, but it is not in quality.
\end{abstract}

Keywords: gender, culture and religious value, concept of agreement and conformity, Buginese life-guidance.

\section{Introduction}

There is always conflict about gender in daily life. Some people say that gender should be supported and a few of them don't think so. This case is related to the existence of gender which does not support women to have the same level with men. Gender is something that has important role in every social life case, culture, economic, government, and politic (Sastriyani, 2009). It is seen that there is equality between right and obligation which makes issue of gender between men and women that has given gender as a phenomenon.

The term of gender is developed as social analysis (Fakih, 1997). Gender is different from sex which is permanently become the attribute of every human being, and it's function can't 
be switched between men and women because it is God's provision, while gender is a term used to describe the difference between men and women as social and cultural man in social life concept that separates the function and role of men and women. Things that are constructed socially and culturally states that men and women have different character. For instance, women are known as blend, emotionally, and motherly creatures. Men are known as a strong, rational, brave, and powerful. Those characters consider men for being more dominant in empowering women.

The relation between gender and Buginese family's existence sees that in gender implementation, come dimensions are related each other in understanding the point of view about gender equality. Those dimensions are life-guidance dimension which consists of cultural and religion value, dimension of social relation in society, patriarchy perception dimension, and social behavior dimension that complete Buginese family life based on the structure and function as performed in the daily real life (Mattulada, 2003).

\section{Research Method}

This research is a descriptive research, type of this research is case study, while the applied approach is phenomenological qualitative approach (Cresswell, 1997, Fakih, M. 2005, and Bungin, 2008). Data collection is conducted by interview with some informants. The informant's determination is conducted purposely based on 5 Buginese man and wife cases with double role, whether those who work as civil servant, entrepreneur, politician, or home industry actor. Data validity verification techniques in qualitative research are: (1) Credibility, (2) Transferability, (3) Dependability, (4) Confirmability (Moleong, 2000).

This research uses qualitative approach with analysis technique as proposed by Miles and Huberman (1992), they are: (1) Data collection, (2) Data reduction, (3) Data display, (4) Conclusion/verification. Furthermore, the analysis is conducted by integrating those four components interactively. The result of qualitative research is more emphasizing the meaning than generalization (Bungin, 2003).

\section{Discussion}

Laurer (2003:49) declares that gender is sociology paradigm that close to sociology in stating a role or behavior from character of men and women in performing something. Behavior as a nature of men and women becomes a structural functionalism phenomenon, gender functionalism and behavior rationalism which need to be understood as a study that gives in-depth analysis.

Parsons (1995) stated that harmony and stability of a family are determined by effectiveness of value consensus. Value system always works and functions to create equilibrium in gender perspective. Although conflicts can arise at any time, when they are reasonable and unthreatening, they will not break family system confessing gender perspective.

Gender in Buginese family life always wants to create a balance by making priority and implementing dimension of life-guidance with cultural values like self esteem (siri'), custom (pangaderreng), respect each other (sipakatau), appreciate each other (sipakalebbi), and religion value that is believing in God ( teepe' laori puang Allataala). This value becomes 
motivation and controller for Buginese family to apply gender equality in family between husband and wife in social society proportionally.

Concerning on 'siri' value, husbands in Buginese family feel that their self-esteem is decreased if they insult the wives (urane ugi'e meddungi siri'na narekko ri callai bainena). Based on pangaderreng value, husbands protect and take care the wives as habit which is done hereditary (urane passampona baine na). Based on sipakatau value, wives should be respected as house wife (bainewe ri pakatau padai indo'na bolae) and husbands as the head of household. For sipakalebbi value, men and women have the same right and obligation (uranewe sibawa bainewe appunai hak sibawa kewajiban). Considering teppe' laori puangalla ta'ala value, wife is a mother who has to be honored (bainewe indo'na mappadeceng keluarga sibawa wija-wija), because heaven lies under mother's feet and women are the pillar of religion.

In Buginese family, these are the examples of life-guidance containing good value to be upheld in facing any problems that related to gender which are usually done by husbands, wives, children, teenagers, families in facing gender equality. Sometimes, if this life-guidance is ignored in gender equality, it causes gender imbalance that can emerge violence in household, exploitation, subordination and women discrimination by giving no chance in public sector, sexual harassment and wives and family neglect.

For Buginese family, gender equality always becomes a consideration, including social relation between men and women existence in society. Social relation related to gender equality in Buginese family can be constructed by developing kinship system, marriage, economic social, and inheritance. In the daily life of Buginese family, they always include social relation by considering that gender existence does not prevent and limit social activities and the relationship between husband and wife, domestically or in public life, Buginese family recommends to stay working along and doing activities together (sipatuo sipatokkong) in getting purpose.

The assumption of structural functional theory is that this important value basis needs to be produced along with the society in maintaining regularity. Societies are considered as a system which are integrated from related parts (Asong, 1996). Functional structural approach states that social group created from sub-parts from which the each sub-part has its own function, therefore the changes between one sub and the others will influence each other (Johnson, 1986; Abmurd and Beilharz, 2003; Narwoko et.al., 2004).

Based on the assumption of those structural functional theories, gender concept in Buginese family is different from gender concept in Western or gender concept in feminism, that is equality and equal partnership (Ambrois, 1992). Concept of gender in Buginese family is an agreement between husband and wife in performing everything and in any role, whether in domestic or public life. Buginese family understands that the equality between men and women will never be same without any differences in performing everything, because men and women have their own function. So does with Buginese family, in taking and performing the role, husband and wife have to do its own role proportionally based on Buginese guidance.

Blood and Wolf (1960) states that some behavior are related to the source distribution during the process of making family decision on gender perspective, such as, 1) wife's domination, 2) 
husband's domination, 3) syncretism or balance, 4) autonomy (husbands and wives have their own power) in taking decision.

The existence of Buginese family gender in behavior and role relates to the elements that influence this gender existence, they are life-guidance, social relation, patriarchy perception and social behavior. These elements are used to understand gender equality, whether in personal, family and society life in taking decision based on the role.

There is no doubt that in Buginese family's life, they still follow patriarchy system stating that men have more dominant than the women (Mattulada, 1993). It seems that there is a perception that in a family, husband's achievement and authority have to be maintained. For Buginese family, they always gives appreciation to the husband as the leader in family who should be respected, because husband is the protector who can guide and lead in daily life as well as a priest in performing worship and religious belief. Indriyani (2006) stated that every people, as a husband or wife, are demanded to own its role, such as a husband who plays the role as the head of household and wife who plays the role as a housewife, thus both should understand their main duty and role. Every husband and wife have to be able to express affection as the driving element in the dynamics of family life to ensure family unity and the existence of gender equality.

Almost all of feminism assumed that gender equality could only be realized by eliminating the patriarchal system (Murdock, 1965; Dwiyanto, 2008). On the contrary, in Buginese families, they appreciate the patriarchal values. They believe that patriarchal values can create regularity and balance in the family, functioned as family controller means.

Gender implementation in Buginese families' perspective relates to behaviors that permeate spiritual moods of husband and wife to build a harmonious equality of gender. Behavior contribution becomes an assessment which has an important role in determining success rate to gender equality to be accepted by the husband and the wife (Sugihastuti and Sastriyani, 200).

Demanded behaviors in gender equality are sipakatau and sipakalebbi (mutual respect), take and give action, willing to deliberation (tudang sipulung), emphasizing the value of a wife and the importance of unity of the family. Through this gender, every individual and family always perform the behavior of self concept in creating wholeness in family atmosphere. Likewise, for those who have dual roles in assisting her husband, taking care of home and family, establishing social order and creating a better and success family life should maintain the principle of life (Mattulada, 1993).

It shows that gender existence has an important role in a society. Gender position, which had been arranged based on its structure and function, is a 'system' that consist of parts which are interrelated where each piece will be constantly seeking balance and harmony (Dwia, 2006). Separation of roles between man and woman in a society, separation of husband and wife role in a core family will create the harmony and also the sense of peace in order to establish social regularity (Amiruddin and Syukur, 2006). In addition, maintaining the behaviors based on value integration in a system is an internalization and socialization process that become a part of actor's awareness and socialization of different gender which functions to produce inequality of personality and equality of taking roles in aspect of life (Ritzer and Goodman, 2004). If there is a function error from one of the structure elements, it will emerge the shock 
which become the dynamic in viewing gender existence as a construction (Guesland, Mc., 2003).

This theory suggests the separation of roles between man and woman in order to establish social regularity, which supports the need of gender equality to be preserved in a social system. These rules are, for example, by providing an important role that woman should stay at house to regulate and to maintain the interest and unity of a family. These interests refer to maintaining the dignity of the husband and integrity that is harmony establishment based on roles performed by women (Goode, 2004). Husbands develop their career outside that won't let competition between husband and wife because that competition will spoil the harmony of married life (Budiman, 1985:16).

Weight in Ritzer (2004) states that in perspective of gender role, there is a social differentiation in core family which cannot be evasived in a society. It is caused by many roles that do not comply with the rules of structural functionalism. Including those perspective stated by Fakih (1996), he says that contemporary approach of women in gender perspective is viewed from structural functionalism and put gender as a behavioral system, personality system, social system and cultural system.

This is in line with what has been proposed by Talcott Pearson in Ritzer (2004) by stating that gender is the behavior of organisms, which perform actions in accordance with the adaptation functions by adapting to environmental changes both internal and external environment in the family and social environment. Through adaptation functions, each organism is able to carry out actions in the personality system to achieve the objective function corresponding to their mobilization. The ability to develop a social system becomes the color of the integration function in performing appropriate action in accordance with the ability to develop a cultural system to perform the functions of maintenance actions.

Buginese family in defining gender equality meaning is always based on a way of life in accordance with the cultural values such as siri, pangaderreng, sipakatau, sipakalebbi, while teppe, the belief of Islam, is a religious value (Mattulada, 2000). Both the cultural and religious values become binding frames of man and wife, motivation and controller for the spouses in understanding gender as a proportional agreement between men and women. Husband and wife on understanding gender equality by implementing the rule of life can create equilibrium in the family and functional in all aspects of life. Hence, gender in Buginese family is framed by cultural value and religious value (Islam).

\section{Conclusion}

Husband and wife in Buginese family understands and interprets gender as an agreement and conformity of function between man and woman in order to take role based on cultural and religious value such as siri', pangaderreng, sipakatau, sipakalebbi and teppe'. They are covered into the rules of life because the values become a binding frames between man and wife in the implementation of gender spouses. Thus, gender in Buginese family is framed by cultural value and religious value.

Implementation of gender equality in Buginese man and wife family is realized in functional and proportional partnership which was constructed based on sipakatau, sipakalebbi and tudang sipulung values. It should be supported by social relation which realize harmony 
based on principle of brotherhood, cooperation and effective communication. It should be also supported 1 by take and give action which was internalized in personality system. While the patriarchal value is required as model of guide, role, control and motivation to create balance of the family.

Gender equality implication can be seen from dual role of women in husband-wife relationship in Buginese family in financial improvement, spirit gift, motivation and achievement to themselves and family, because Buginese society do not prohibit the wife to work outside and religion does not forbid the wife to assist the husband in making money (instrumental role) as long as she is able to protect her self-esteem (siri') and has an agreement from the husband. Yet, the time to accompany her husband at home at any time during the day is very less in quantity but not quality.

\section{References}

Abmurd, and Beilharz, P. (2003). Teori-teori Sosial (Terjemahan oleh: Sigit Jatmiko, Judul Asli: Social Theory). Yogyakarta: Pustaka Pelajar.

Ambrois, V. (1992). A Treatise on Gender General Sociology. New York: Dover.

Ambrois, V. (2002). Sociology after Postmodernism. London: Sage.

Amiruddin dan M., Syukur. (2006). Perempuan Pedagang Antarpulau dalam Keterlibatan

Pengambilan Keputusan pada Keluarga Bugis (Studi Kasus di Kecamatan Sibulue Kabupaten Bone, Provinsi Sulawesi Selatan). http://www.unhas.or.id.

Asong, E. (1996). Human Communication Theory: Social determinant. New York: Holt, Rinehart, Winston.

Budiman, A. (2005). Pembagian Kerja Secara Seksual, Sebuah Pembahasan Sosiologis tetang Peran Perempuan di dalam Masyarakat. Jakarta: Gramedia.

Bungin, B. (2003). Analisis Data Penelitian Kualitatif dan Kuantitatif. Jakarta: PT. Raja Grafindo Persada.

Bungin, B. (2008). Metodologi Penelitian Sosial Format-format Kuantitatif dan Kualitatif. Penerbit: Airlangga University Press.

Cresswell, J. W. (1997). Research Design Qualitative and Quantitative Approach. London: Sage Publication.

Dwiyanto, M. (2008). Persoalan Pokok Mengenai Feminisme dan Relepansinya. Jakarta: PT. Gramedia Pustaka Utama Bekerjasama dengan Kalyanamitra.

Dwia, B. K. (2006). Memahami Jender. Jakarta: Teplok Press.

Fakih, M. (1996). Analisis Gender dan Transformasi Sosial. Yogyakarta: Pustaka Pelajar Offset.

Fakih, M. (2005). Format-format Penelitian Sosial. Jakarta: PT. Raja Grafindo Persada.

Goode, W. J. (2004). Sosiologi Keluarga. Jakarta: Bumi Aksara Jaya.

Goode, William J. 2007. Social Theory Today: Panduan Sistematis Tradisi dan Tren Terdepan Teori Sosial. Yogyakarta: Pustaka Pelajar.

Guesland, Mc, (2003). Gender Construction. Feminism \& Psychology 10:11-29.

Indriyani, A. (2006). Gambaran Kehidupan Sosial Keluarga. Jakarta: Penerbit Djambatan.

Johnson, J. (1986). The Structure of Sociological Theory. California: Wadsworth Publishing 
Company.

Mattulada. 1985. Latoa. Yogyakarta: Gadjah Mada University Press.

Mattulada. (1993). Kajian Bugis dan Makassar. Jakarta: Mandar Maju.

Mattulada. (2000). Sosial, Kultur dan Masyarakat. Jakarta: Mandar Maju.

Mattulada. (2003). Dinamika Masyarakat Indonesia. Jakarta: Penerbit Genesindo.

Murdock, P. (1965). Feminist Thought. New York: John Wiley and Sons.

Narwoko, J. Dwi dan Suyanto, B. (2004). Sosiologi. Pengantar dan Terapan. Edisi Revisi. Jakarta: Penerbit Prenada Media.

Parsons, T. (1995). The Study of Sociology. New Delhi: India Offset Press.

Ritzer, G. (2004). Sosiologi: Ilmu Pengetahuan Berparadigma Ganda (terjemahan oleh: Alimandan, Judul Asli: Sociology: a multiple paradigm science). Jakarta: PT. Raja Grafindo Persada.

Ritzer, G. \& Goodman, D. J. (2004). Teori Sosiologi Modern. Terjemahan oleh Alimandan. Jakarta: Prenada Media.

Sastriyani, and S. Hariti. (2009). Gender and Politics. Yogyakarta: Tiara Wacana.

Sugihastuti, A., dan Sastriyani, N. (2007). Keadilan dan Kesetaraan Jender (Perspektif Islam). Jakarta: Tim Pemberdayaan Perempuan. 